\title{
Effect of Different Fruit Peel Powders as Natural Fertilizers on Growth of Okra (Abelmoschus esculentus L.)
}

\author{
S.G.A.R.M. Dayarathna ${ }^{1}$ and Brintha Karunarathna ${ }^{1 *}$
}

Date Received: $30^{\text {th }}$ November 2019 / Date Accepted: $3^{\text {rd }}$ January 2020

\begin{abstract}
Purpose: Fruit peels waste is one of the waste accumulate in huge quantity every day. It is a serious problem and need to be managed to make environment free from pollution. Fruit peels are very rich in macro and micro nutrients that are beneficial for plant growth. By using fruit peel as fertilizer we can reduce load of wastes and can get more benefits than inorganic fertilizer.

Research Method: The experiment was carried out in a Completely Randomized Design with six treatments having twenty replicates. Treatments were, recommended fertilizer application at basal and topdressing (T1, control), half dose of recommended fertilizer application at basal and topdressing times with $1 \mathrm{~g}$ of banana peel powder (T2), $1 \mathrm{~g}$ of pomegranate peel powder (T3), $1 \mathrm{~g}$ of orange peel powder (T4), $0.5 \mathrm{~g}$ each of banana and pomegranate peel powders (T5) and $0.5 \mathrm{~g}$ each of orange and banana peel powders (T6) at both times. All agronomic practices were followed as per Department of Agriculture, Sri Lanka except fertilizers.

Findings : The results reveals that application of fruit peel powder at basal and top dressing had significant differences $(P<0.05)$ on plant height, number of leaves per plant, leaf area, chlorophyll content, days to $50 \%$ and $100 \%$ flowering, dry weights of leaves, stem, root and fruit, fruit length and girth. At $1^{\text {st }}, 2^{\text {nd }}, 3^{\text {rd }}$ and $4^{\text {th }}$ picking, and the highest value was obtained in T6 and lowest value in T1.

Originality/Value : Application of fruit peel powder into the soil leads to improve growth and yield of okra in sandy regosol compared to recommended inorganic fertilizer and present study suggested that, among the all tested treatments, half recommended fertilizer application at basal and topdressing times with $0.5 \mathrm{~g}$ each of orange and banana peel powders at both times would be the most suitable fruit peel powders to get higher growth and yield of okra in sandy regosol.
\end{abstract}

Keywords: Banana peel powder, okra, orange peel powder, pomegranate peel powder

\section{INTRODUCTION}

Okra (Abelmoschus esculentus (L.) Moench) is a vegetable plant of the family Malvaceae growing as an annual crop in tropical and sub-tropical areas of the world. Cultivation and consumption of okra are popular in Sri Lanka due to its nutritional composition and elevated medicinal value. It contains considerable amounts of protein, carbohydrate, fiber, vitamin A, B, C, Ca, P and $\mathrm{Fe}$ (Sachan et al., 2017). Okra is much useful for human to prevent numerous diseases and ageing, promote immunity, and improve health care (Ibeawuchi et al., 2005), control cholesterol thereby reduce cardiovascular diseases (Dubey and Mishra, 2017). The high fiber content helps to stabilize blood sugar by regulating the rate at which sugar is absorbed from the intestinal tract, and to reduce digestive issues. Besides, it improves heart health, control body cholesterol level and promote healthiness during pregnancy (Gemede et al., 2015). Okra is a tolerant crop to a wide range of climatic conditions (Akanbi et al., 2010). However, growth and yield of okra depend

\footnotetext{
Department of Crop Science, Faculty of Agriculture, Eastern University, Sri Lanka

brinthak@esn.ac.lk
}

(D)http://orcid.org/0000-0002-3773-9402 
on factors such as seed quality, soil nutrition, climatic condition and cultural practices as well as on the use of plant growth regulators (Shahid et al., 2013). Low yield resulting from poor nutrient status of the soil has been identified as one of the major factors limiting okra production (Ajayi et al., 2017).

Fruit peel waste accumulates in considerable quantities daily, at domestic and industrial levels. Most frequently, people remove fruit skin and throw away as a waste. It is a vital issue, especially at industrial level that needs to be appropriately managed (Jariwala and Syed, 2016) to make the environment free from pollutants. Fruit peels are very rich in macro and micro nutrients that are indispensable for plant growth (Ibrahim et al., 2016). Fruit scraps are utilized as fertilizers to enhance soil fertility and enrich soil micro biota due to their mineral contents essential for plant growth. Besides, some active compounds from fruit peels seeds have insecticidal and antifungal properties against some plant pathogens (Singh et al., 2017). Therefore, fruit peels can be used as a natural fertilizer in crop production. By using fruit peel as a fertilizer we can reduce the loads of wastes lying around receiving further benefits. Fruit peel powders can also be used to regulate $\mathrm{pH}$ in soil, increase and improve soil fertility and morphology, fulfill requirements of nutrients, kill harmful insect pests and nematodes, especially in citrus varieties (Mercy et al., 2014). Furthermore, it would help to substitute costly an environmentally unfriendly inorganic fertilizers directing towards sustainable and quality crop production.

Peels of tropical fruits such as banana, papaya, pineapple, mango, orange, and pomegranate are the frequently available materials in large quantities in Sri Lanka. Such, can beused as natural fertilizer for the plants. Banana is consumed in a large quantity in Sri Lanka. Peel represents about $40 \%$ of total weight of fresh fruit (Fatemeh et al., 2012). Banana fruit peels are rich in $\mathrm{K}, \mathrm{Ca}, \mathrm{Na}$, $\mathrm{Fe}, \mathrm{Mn}$ and $\mathrm{Br}$ (Anhwange et al., 2009). From orange (Citrus sinensis) a large amount of peel is produced annually. It is primarily a waste, but it is a good source for molasses, pectin and limonene (Rafiq et al., 2018). Pomegranate fruit peel is an inedible part during processing of pomegranate juice. Peel represents $26-30 \%$ of total fruit weight and it has notable amounts of phenolic compounds, including flavonoids and hydrolysable tannins (Rowayshed et al., 2013) and $92 \%$ of antioxidant activity (Ismail et al., 2012). Pomegranate fruit peel has $\mathrm{K}, \mathrm{N}, \mathrm{Ca}, \mathrm{P}$, $\mathrm{Mg}, \mathrm{Na}$ and it has micronutrients like $\mathrm{B}, \mathrm{Fe}, \mathrm{Zn}$, $\mathrm{Cu}, \mathrm{Mn}$ (Rowayshed et al., 2013). Therefore, the present study was aimed to study the effect of application of banana, orange and pomegranate fruit peel powders on growth and yield of okra.

\section{MATERIALS AND METHODS}

A pot experiment was carried out at the open field at Crop Farm of Eastern University, Sri Lanka located in the Eastern Province of Sri Lanka which falls under low country dry zone. Annual temperature varies from $28^{\circ} \mathrm{C}$ to $32^{\circ} \mathrm{C}$ and annual rainfall varies from $1400 \mathrm{~mm}$ to $1680 \mathrm{~mm}$. The soil of experimental site is a sandy regosol. For this experiment, Okra variety Haritha seeds were used. Experiment was carried out in a Completely Randomized Design (CRD) with six treatments having twenty replicates. Treatments are recommended fertilizer application at basal and topdressing (Control T1), half recommended fertilizer application at basal and topdressing times with $1 \mathrm{~g}$ of banana peel powder (T2), $1 \mathrm{~g}$ of pomegranate peel powder (T3), $1 \mathrm{~g}$ of orange peel powder (T4), $0.5 \mathrm{~g}$ each of banana and pomegranate peel powders (T5) and $0.5 \mathrm{~g}$ each of orange and banana peel powders (T6) at both times. Fruit peels were collected separately from the market, Batticaloa.

Collected fruit peels were cleaned and foreign materials were removed. Then the peels were cut in to small pieces of $1-5 \mathrm{~cm}$ and air dried under natural sunlight for $20-25$ days. Thereafter, the dried fruit peels were powdered using a grinder separately. Subsequently those were sieved separately using sieve of $2 \mathrm{~mm}$ in size and stored at room temperature (Jariwala and Syed, 2016). After that $1 \mathrm{~g}$ of banana, pomegranate and orange peel powder each were measured separately and filled into pots and sealed air tightly. Also mixtures of $0.5 \mathrm{~g}$ of banana and 0.5 g pomegranate peel powders and $0.5 \mathrm{~g}$ of banana and $0.5 \mathrm{~g}$ orange peel powders were sealed 
separately in the similar manner and labeled for later identification.

Pots with $45 \mathrm{~cm}$ height and $30 \mathrm{~cm}$ diameter were used in this experiment. Pots were prepared by adding equal volume of soil and inorganic and fruit peel powders were applied as per the treatments. Two days after scarified okra seeds were sown at two seeds per bag with 1-2 cm depth. All agronomic practices were followed as per recommendations of the Department of Agriculture, Sri Lanka except fertilizers. 80\% water holding capacity was maintained in all pots. Growth and yield parameters were measured using destructive sampling method. Collected data was analyzed using parametric and nonparametric statistics.

\section{RESULTS AND DISCUSSION}

\section{Plant height}

Plant height significantly varied $(\mathrm{P}<0.05)$ among the tested treatments at $2^{\text {nd }}, 6^{\text {th }}$ and $8^{\text {th }}$ WAP (Table 01). At 2 WAP tallest plant was recorded in T2 $(17 \mathrm{~cm})$, followed by $\mathrm{T} 6(16 \mathrm{~cm})$ and T5 $(15.83 \mathrm{~cm})$ while the lowest plant height was recorded in $\mathrm{T} 1(13.5 \mathrm{~cm})$. Banana fruit peel has more $\mathrm{K}$ and it may help to create new cells, which then organize into plant tissues may be the reason for tallest plant in $\mathrm{T} 2, \mathrm{~T} 6$ and $\mathrm{T} 5$. At $6^{\text {th }}$ and $8^{\text {th }}$ WAP, plant height did not show a significant difference among tested treatments except T1. Application of fruit peel powder into the soil leads to increase soil nutrients level and that may be the reason to increase plant height in fruit peel applied treatments compared with T1. These results are in agreement with Mercy et al. (2014) who stated that height of the fenugreek plants were higher in fruit peel powder applied soil than the control. Kadir et al. (2016) reported that fruit peels significantly enhanced the shoot height of Solanum scabrum plants compared with untreated plants. Further, Tan and So (2018) stated that holy basil plant height was increased when banana peel based biochar prepared at different pyrolysis temperatures were applied.

\section{Leaf area}

Plant grown with higher concentration of fertilizers produces larger leaf area (Kang and Iersel, 2004). Application of fruit peel powder significantly influenced $(\mathrm{P}<0.05)$ the leaf area at $6^{\text {th }}$ and $8^{\text {th }}$ WAP. At $6^{\text {th }}$ and $8^{\text {th }}$ WAP, the highest leaf area was recorded in T2 $\left(667.17 \mathrm{~cm}^{2}\right.$ and $741.90 \mathrm{~cm}^{2}$ respectively) followed by T6 (642.88 $\mathrm{cm}^{2}$ and $658.08 \mathrm{~cm}^{2}$ respectively) while the lowest leaf area was recorded in T1 $\left(333.59 \mathrm{~cm}^{2}\right.$ and $566.40 \mathrm{~cm}^{2}$ respectively). These findings are agreeable with Mercy et al. (2014) who stated that leaf area of the rye plant was higher in fruit peel powder applied soil than control and Wazir et al. (2018) noted that application of banana peel as an organic fertilizer into the soil increase leaf area of pea plant. However, there was no variation in leaf area between T2 and T6 at $6^{\text {th }}$ WAP.

Table 01: Plant height $(\mathrm{cm})$ of okra with respect to treatment during the experiment period

\begin{tabular}{ccccc}
\hline Treatment & $2^{\text {nd }}$ WAP & $4^{\text {th }}$ WAP & $6^{\text {th }}$ WAP & $8^{\text {th }}$ WAP \\
\hline T1 & $13.50 \pm 0.54 \mathrm{c}$ & $25.00 \pm 0.24$ & $26.27 \pm 2.32 \mathrm{~b}$ & $35.67 \pm 0.47 \mathrm{~b}$ \\
T2 & $17.00 \pm 0.35 \mathrm{a}$ & $29.33 \pm 0.85$ & $33.00 \pm 0.91 \mathrm{a}$ & $60.00 \pm 2.27 \mathrm{a}$ \\
T3 & $15.17 \pm 0.43 \mathrm{bac}$ & $29.30 \pm 0.94$ & $32.00 \pm 0.81 \mathrm{a}$ & $53.00 \pm 1.47 \mathrm{a}$ \\
T4 & $14.67 \pm 0.12 \mathrm{bc}$ & $30.33 \pm 2.04$ & $32.67 \pm 2.49 \mathrm{a}$ & $57.67 \pm 2.95 \mathrm{a}$ \\
T5 & $15.83 \pm 0.43 \mathrm{ba}$ & $28.00 \pm 0.23$ & $31.33 \pm 0.94 \mathrm{a}$ & $56.67 \pm 1.17 \mathrm{a}$ \\
T6 & $16.00 \pm 0.41 \mathrm{ba}$ & $31.33 \pm 2.01$ & $39.00 \pm 0.85 \mathrm{a}$ & $56.33 \pm 2.01 \mathrm{a}$ \\
F test & $*$ & $\mathrm{~ns}$ & $* *$ & $* *$ \\
\hline
\end{tabular}

Values represent mean $\mp$ standard error of four replicates. F test: - *: P<0.05; ns: not significant; **: P<0.01; Means followed by the same letter in each column are not significantly different according to the Duncan's Multiple Range Test at 5\% level. 
Table 02: $\quad$ Leaf area $\left(\mathrm{cm}^{2}\right)$ with respect to treatment during the experiment period

\begin{tabular}{ccccc}
\hline Treatment & $2^{\text {nd }}$ WAP & $4^{\text {th }}$ WAP & $6^{\text {th }}$ WAP & $8^{\text {th }}$ WAP \\
\hline T1 & $34.52 \pm 2.92$ & $147.3 \pm 5.32$ & $333.59 \pm 4.04 \mathrm{c}$ & $566.40 \pm 10.91 \mathrm{~b}$ \\
T2 & $38.03 \pm 3.17$ & $215.0 \pm 4.43$ & $667.17 \pm 9.56 \mathrm{a}$ & $741.90 \pm 10.00 \mathrm{a}$ \\
T3 & $37.41 \pm 3.26$ & $172.7 \pm 3.30$ & $480.96 \pm 7.94 \mathrm{~b}$ & $598.96 \pm 9.28 \mathrm{~b}$ \\
T4 & $37.30 \pm 1.96$ & $234.7 \pm 4.28$ & $537.69 \pm 9.79 \mathrm{ba}$ & $622.18 \pm 9.14 \mathrm{~b}$ \\
T5 & $33.31 \pm 3.01$ & $214.3 \pm 6.63$ & $526.43 \pm 9.40 \mathrm{ba}$ & $612.01 \pm 9.16 \mathrm{~b}$ \\
T6 & $31.54 \pm 5.82$ & $243.7 \pm 5.39$ & $642.88 \pm 9.03 \mathrm{a}$ & $658.08 \pm 9.95 \mathrm{ba}$ \\
F test & $\mathrm{ns}$ & $\mathrm{ns}$ & $* *$ & $*$ \\
\hline
\end{tabular}

Values represent mean $\mp$ standard error of four replicates. F test: - *: P<0.05; ns: not significant; **: P<0.01; Means followed by the same letter in each column are not significantly different according to the Duncan's Multiple Range Test at 5\% level.

\section{Root length}

There were significant differences $(\mathrm{P}<0.01)$ in root length which measured from collar region to tip of the root at $2^{\text {nd }}, 4^{\text {th }}, 6^{\text {th }}$ and $8^{\text {th }}$ WAP as shown in table 3. T6 recorded the maximum root length and $\mathrm{T} 1$ recorded the lowest root length from $2^{\text {nd }}$ WAP to $8^{\text {th }}$ WAP. At $8^{\text {th }}$ WAP, the highest root length was recorded in T6 $(49.33 \mathrm{~cm})$, followed by T4 $(46.33 \mathrm{~cm}), \mathrm{T} 2(43 \mathrm{~cm})$ and while the lowest root length was recorded in T1 (16.67 $\mathrm{cm})$. However, there was no variation among T6, T4 and T2 in root length at $8^{\text {th }}$ WAP. Mineral nutrients are important for plant root growth (Fageria and Moreira, 2011). Amin et al. (2015) stated that Potassium supplement improves root and shoot growth and enhance plant nutrient uptake. Phosphorus and iron increase plant root length (Ding et al., 2018). The presence of Cytokinins in fruit peels could be another reason of increased root length (Singh and Prasad, 2014). Those may be the reasons for increase root length in fruit peel applied okra plants compared with control. It is in line with Sakpere et al. (2018) who noted that root length was enhanced by fruit peels treated Solanum scabrum plants than untreated plants.

Table 03: Root length $(\mathrm{cm})$ with respect to treatment during the experiment period

\begin{tabular}{ccccc}
\hline Treatment & $2^{\text {nd }}$ WAP & $4^{\text {th }}$ WAP & $6^{\text {th }}$ WAP & $8^{\text {th }}$ WAP \\
\hline T1 & $7.00 \pm 0.20 \mathrm{~d}$ & $12.00 \pm 0.20 \mathrm{~d}$ & $14.67 \pm 0.23 \mathrm{c}$ & $16.67 \pm 0.77 \mathrm{c}$ \\
T2 & $8.33 \pm 0.23 \mathrm{dc}$ & $14.17 \pm 0.31 \mathrm{cb}$ & $23.00 \pm 1.08 \mathrm{a}$ & $43.00 \pm 2.94 \mathrm{a}$ \\
T3 & $8.00 \pm 0.20 \mathrm{dc}$ & $13.17 \pm 0.31 \mathrm{~cd}$ & $18.00 \pm 0.40 \mathrm{cb}$ & $29.83 \pm 0.11 \mathrm{~b}$ \\
T4 & $10.0 \pm 0.20 \mathrm{ba}$ & $15.33 \pm 0.23 \mathrm{~b}$ & $19.33 \pm 0.62 \mathrm{~b}$ & $46.33 \pm 1.31 \mathrm{a}$ \\
T5 & $9.17 \pm 0.58 \mathrm{bc}$ & $14.17 \pm 0.42 \mathrm{cb}$ & $17.00 \pm 0.40 \mathrm{cb}$ & $31.83 \pm 1.85 \mathrm{~b}$ \\
T6 & $11.2 \pm 0.11 \mathrm{a}$ & $17.00 \pm 0.40 \mathrm{a}$ & $23.33 \pm 1.24 \mathrm{a}$ & $49.33 \pm 1.84 \mathrm{a}$ \\
F test & $* *$ & $* *$ & $* *$ & $* *$ \\
\hline
\end{tabular}

Values represent mean $\mp$ standard error of four replicates. F test: - **: $P<0.01$; Means followed by the same letter in each column are not significantly different according to the Duncan's Multiple Range Test at $5 \%$ level. 


\section{Chlorophyll content}

Chlorophyll content was measured with the help of SPAD meter. There was a significant change $(\mathrm{P}<0.05)$ noted at $4^{\text {th }}, 6^{\text {th }}$ and $8^{\text {th }}$ WAP as shown in table 4 . From $4^{\text {th }}$ to $8^{\text {th }}$ week, T2 showed maximum chlorophyll content and $\mathrm{T} 1$ recorded the lowest chlorophyll content. At $8^{\text {th }}$ WAP, the highest chlorophyll content was recorded in T2 (89.00), followed by T5 (80.20), T3 (80.03), T6 (69.90) and while the chlorophyll content was recorded in T1 (32.73). The findings are agreeable with Bakry et al. (2016) who stated that banana peel extract significantly increased chlorophyll a, chlorophyll b, total carotenoids and consequently total pigments and maximum increase of the photosynthetic pigments. However, no difference was noted among T2, T5, T3 and T6 in $8^{\text {th }}$ WAP.

\section{Days for $50 \%$ and 100\% flowering}

Days for $50 \%$ and $100 \%$ flowering of okra varied significantly $(\mathrm{P}<0.05)$ due to the fruit peel powder application as confirmed by $P$ value of 0.027 and chi square value of 12.67 at both stages shown in table 5. Minimum duration of 35 and 37 days were taken by $\mathrm{T} 6$ to attain the $50 \%$ and $100 \%$ flowering respectively. Longer time period of 40 and 44 days were taken by $\mathrm{T} 1$ for $50 \%$ and $100 \%$ flowering respectively. Theoretically, additional need of potassium application for flowering and banana peel rich in potassium may be the reason for the shortest period for flowering on T6 and $\mathrm{T} 2$.

Table 04: Chlorophyll content with respect to treatment during the experiment period

\begin{tabular}{ccccc}
\hline Treatment & $2^{\text {nd }}$ WAP & $4^{\text {th }}$ WAP & $6^{\text {th }}$ WAP & $8^{\text {th }}$ WAP \\
\hline T1 & $38.17 \pm 1.74$ & $36.63 \pm 0.87 \mathrm{~b}$ & $38.37 \pm 0.35 \mathrm{c}$ & $32.73 \pm 2.30 \mathrm{~b}$ \\
T2 & $39.70 \pm 0.74$ & $43.33 \pm 0.72 \mathrm{a}$ & $47.10 \pm 0.54 \mathrm{a}$ & $89.00 \pm 3.85 \mathrm{a}$ \\
T3 & $37.87 \pm 0.67$ & $41.80 \pm 0.49 \mathrm{a}$ & $45.77 \pm 0.43 \mathrm{ba}$ & $80.03 \pm 5.42 \mathrm{a}$ \\
T4 & $40.90 \pm 1.52$ & $42.83 \pm 0.58 \mathrm{a}$ & $46.90 \pm 1.12 \mathrm{a}$ & $63.67 \pm 2.47 \mathrm{ba}$ \\
T5 & $39.77 \pm 2.12$ & $43.30 \pm 1.74 \mathrm{a}$ & $43.63 \pm 1.10 \mathrm{~b}$ & $80.20 \pm 3.74 \mathrm{a}$ \\
T6 & $38.38 \pm 1.19$ & $40.13 \pm 1.16 \mathrm{ba}$ & $44.77 \pm 0.20 \mathrm{ba}$ & $69.90 \pm 2.46 \mathrm{a}$ \\
F test & ns & $*$ & $* *$ & $*$ \\
\hline
\end{tabular}

Values represent mean $\mp$ standard error of four replicates. F test: - *: $P<0.05$; ns: not significant; **: P<0.01; Means followed by the same letter in each column are not significantly different according to the Duncan's Multiple Range Test at 5\% level.

Table 05: Days for $50 \%$ and $100 \%$ flowering with respect to treatment during the experiment period

\begin{tabular}{ccc}
\hline Treatment & Days for $50 \%$ flowering & Days for $100 \%$ flowering \\
\hline T1 & 40 & 44 \\
T2 & 36 & 39 \\
T3 & 38 & 40 \\
T4 & 39 & 41 \\
T5 & 39 & 42 \\
T6 & 35 & 37 \\
$P$ value & 0.027 & 0.027 \\
Chi - square & 12.67 & 12.67 \\
\hline
\end{tabular}


These results are in agreement with Shah et al. (2014) who stated that more days to flowering were recorded in control plots, while fewer days to flowering were observed in plots received potassium. According to Larik et al. (1999) potassium is required to increase carbon exchange, enhance carbohydrate movements, stimulates early growth and decreases the translocation of photosynthates into storage organs/sinks and consequently leads to the early initiation of flowers.

\section{Dry weight of leaves}

Dry weight of leaves was significantly influenced $(\mathrm{P}<0.05)$ with the application of different fruit peel powder at $4^{\text {th }}, 6^{\text {th }}$ and $8^{\text {th }}$ WAP as shown in table 6 . At $2^{\text {nd }}$ WAP, there was no significant difference $(\mathrm{P}>0.05)$ among treatments. However, at $4^{\text {th }}$ and $6^{\text {th }}$ WAP, the maximum dry weight of leaves were recorded in $\mathrm{T} 2$, followed by $\mathrm{T} 6$ while the lowest fresh weight of okra leaves were recorded in T1. At $8^{\text {th }}$ WAP, the maximum dry weight of leaves were recorded in T2 (4.23 g) and while the lowest fresh weight of okra roots were recorded in T1 $(2.12 \mathrm{~g})$. But at $8^{\text {th }} \mathrm{WAP}$, dry weight of leaves were not significantly $(\mathrm{P}>0.05)$ different among treatments except $\mathrm{T} 1$.

\section{Dry weight of stem}

At $6^{\text {th }}$ WAP, the maximum dry weight of stems were recorded as T2 $(8.06 \mathrm{~g})$, followed by T6
$(6.67 \mathrm{~g})$, T5 $(6.71 \mathrm{~g})$ and while the minimum fresh weight of okra stems were recorded as T1 $(2.90 \mathrm{~g})$. At $8^{\text {th }}$ WAP, okra stems did not show a significant difference among treatments except T1. Fruit peel contains substantial amounts of macronutrients which are essential for plant growth (Anhwange et al., 2009). It helps to increase the plant growth such as plant height, the number of branches that help to increase dry weight of stems. Bakry et al. (2016) found that foliar application of banana peel extract increased shoot dry weight of quinoa plants compared to the untreated plants.

\section{Dry weight of root}

There were significant differences $(\mathrm{P}<0.05)$ at $2^{\text {nd }}$, $4^{\text {th }}$ and $6^{\text {th }}$ WAP. All four stages, T6 recorded the maximum dry weight of roots and $\mathrm{T} 1$ recorded the lowest dry weight of roots (Table 8). Phosphorus promotes rooting, flowering, and fruit set and $\mathrm{K}$ is essential for stem and root growth and protein analysis (Wazir et al., 2018). Presence of growth promoting factors and macro and micronutrients in the fruit peel powder may have enhanced the growth of the plants. This may be the reason for high dry weight of roots in T6. Bakry et al. (2016) noted that foliar application of banana peel extract helps to increased root dry weight of quinoa plants compared to the untreated plants. Sakpere et al. (2018) noted that root length of Solanum scabrum plants were enhanced by fruit peel treated plants than untreated plants.

Table 06: Dry weight (g) of leaves with respect to treatment during the experiment period

\begin{tabular}{ccccc}
\hline Treatment & $2^{\text {nd }}$ WAP & $4^{\text {th }}$ WAP & $6^{\text {th }}$ WAP & $8^{\text {th }}$ WAP \\
\hline T1 & $0.33 \pm 0.16$ & $0.96 \pm 0.06 \mathrm{c}$ & $2.44 \pm 0.10 \mathrm{~d}$ & $2.12 \pm 0.21 \mathrm{~b}$ \\
T2 & $0.21 \pm 0.01$ & $2.36 \pm 0.15 \mathrm{a}$ & $4.14 \pm 0.15 \mathrm{a}$ & $4.23 \pm 0.32 \mathrm{a}$ \\
T3 & $0.44 \pm 0.19$ & $1.26 \pm 0.37 \mathrm{bc}$ & $3.16 \pm 0.25 \mathrm{c}$ & $3.96 \pm 0.29 \mathrm{a}$ \\
T4 & $0.12 \pm 0.01$ & $1.45 \pm 0.08 \mathrm{bac}$ & $3.46 \pm 0.17 \mathrm{bc}$ & $3.72 \pm 0.26 \mathrm{a}$ \\
T5 & $0.49 \pm 0.21$ & $1.09 \pm 0.18 \mathrm{c}$ & $3.57 \pm 0.06 \mathrm{cb}$ & $3.83 \pm 0.44 \mathrm{a}$ \\
T6 & $0.21 \pm 0.01$ & $2.17 \pm 0.30 \mathrm{ba}$ & $3.90 \pm 0.10 \mathrm{~b}$ & $3.99 \pm 0.29 \mathrm{a}$ \\
F test & $\mathrm{ns}$ & $*$ & $* *$ & $*$ \\
\hline
\end{tabular}

Value represent mean $\mp$ standard error of four replicates. F test: - *: P<0.05; ns: not significant; **: $P<0.01$; Means followed by the same letter in each column are not significantly different according to the Duncan's Multiple Range Test at 5\% level. 
Table 07: Dry weight (g) of stems with respect to treatment during the experiment period

\begin{tabular}{ccccc}
\hline Treatment & $2^{\text {nd }}$ WAP & $4^{\text {th }}$ WAP & $6^{\text {th }}$ WAP & $8^{\text {th }}$ WAP \\
\hline T1 & $0.04 \pm 0.01$ & $0.57 \pm 0.10$ & $2.90 \pm 0.29 \mathrm{c}$ & $4.49 \pm 0.12 \mathrm{~b}$ \\
T2 & $0.06 \pm 0.01$ & $0.99 \pm 0.02$ & $8.06 \pm 0.07 \mathrm{a}$ & $11.90 \pm 0.32 \mathrm{a}$ \\
T3 & $0.03 \pm 0.01$ & $0.76 \pm 0.22$ & $6.07 \pm 0.20 \mathrm{~b}$ & $10.10 \pm 0.52 \mathrm{a}$ \\
T4 & $0.04 \pm 0.01$ & $0.68 \pm 0.02$ & $6.32 \pm 0.27 \mathrm{~b}$ & $8.49 \pm 1.49 \mathrm{a}$ \\
T5 & $0.04 \pm 0.01$ & $0.69 \pm 0.11$ & $6.71 \pm 0.36 \mathrm{ba}$ & $9.89 \pm 1.37 \mathrm{a}$ \\
T6 & $0.05 \pm 0.01$ & $0.99 \pm 0.08$ & $6.67 \pm 0.49 \mathrm{ba}$ & $10.5 \pm 0.68 \mathrm{a}$ \\
F test & $\mathrm{ns}$ & $\mathrm{ns}$ & $* *$ & $*$ \\
\hline
\end{tabular}

Values represent mean $\mp$ standard error of four replicates. F test: - *: P<0.05; ns: not significant; **: P<0.01; Means followed by the same letter in each column are not significantly different according to the Duncan's Multiple Range Test at 5\% level.

Table 08: Dry weight (g) of roots with respect to treatment during the experiment period

\begin{tabular}{ccccc}
\hline Treatment & $2^{\text {nd }}$ WAP & $4^{\text {th }}$ WAP & $6^{\text {th }}$ WAP & $8^{\text {th }}$ WAP \\
\hline T1 & $0.01 \pm 0.01 \mathrm{~b}$ & $0.17 \pm 0.01 \mathrm{~d}$ & $0.83 \pm 0.06 \mathrm{~b}$ & $1.66 \pm 0.20$ \\
T2 & $0.02 \pm 0.01 \mathrm{~b}$ & $0.39 \pm 0.07 \mathrm{~b}$ & $2.01 \pm 0.34 \mathrm{a}$ & $4.13 \pm 0.37$ \\
$\mathrm{~T} 3$ & $0.02 \pm 0.01 \mathrm{~b}$ & $0.21 \pm 0.01 \mathrm{~cd}$ & $1.63 \pm 0.17 \mathrm{ba}$ & $2.45 \pm 0.19$ \\
$\mathrm{~T} 4$ & $0.01 \pm 0.01 \mathrm{~b}$ & $0.31 \pm 0.04 \mathrm{cbd}$ & $1.87 \pm 0.29 \mathrm{ba}$ & $3.72 \pm 0.76$ \\
$\mathrm{~T} 5$ & $0.02 \pm 0.01 \mathrm{~b}$ & $0.36 \pm 0.01 \mathrm{cb}$ & $1.50 \pm 0.33 \mathrm{ba}$ & $3.33 \pm 0.50$ \\
T6 & $0.03 \pm 0.01 \mathrm{a}$ & $0.56 \pm 0.01 \mathrm{a}$ & $2.63 \pm 0.10 \mathrm{a}$ & $4.37 \pm 0.45$ \\
F test & $*$ & $* *$ & $*$ & $\mathrm{~ns}$ \\
\hline
\end{tabular}

Values represent mean $\mp$ standard error of four replicates. F test: - *: P<0.05; ns: not significant; **: P<0.01; Means followed by the same letter in each column are not significantly different according to the Duncan's Multiple Range Test at 5\% level.

\section{Number of fruits per plant}

Application of fruit peel powder did not influence $(\mathrm{P}>0.05)$ the number of fruits per plant as confirmed with $P$ values of $0.109,0.078,0.075$, 0.197 and chi square values of 9.00, 9.90, 10.00, 7.33 at $1^{\text {st }}, 2^{\text {nd }}, 3^{\text {rd }}$ and $4^{\text {th }}$ picking respectively (Table 9). Contradictory findings were noted by Colpan et al. (2013) who stated that with an increase in potassium application, there was an increase and then a decrease in the fruit number of tomato plant and Mazed et al. (2015) stated that the highest number of pods per mung bean plant was recorded from potassium whereas, the lowest number of pods per plant was found from control treatment.

\section{Fruit length and girth}

The data presented in table 10 clearly indicated that the fruit peel application played a significant role in length of fruits. At $1^{\text {st }}, 3^{\text {rd }}$ and $4^{\text {th }}$ picking there was a significant difference $(\mathrm{P}<0.01)$ among treatments. At $1^{\text {st }}, 2^{\text {nd }}, 3^{\text {rd }}$ and $4^{\text {th }}$ pickings, maximum length of fruits were observed in T6 while minimum length of fruits were observed in T1. Colpan et al. (2013) stated that when potassium levels are low, fruits are small and when potassium levels are high, fruits are too large. It is agreed with the present study. 
Table 09: Number of fruits per plant at each picking with respect to treatment during the experiment period

\begin{tabular}{ccccc}
\hline Treatment & $1^{\text {st }}$ picking & $2^{\text {nd }}$ picking & $3^{\text {rd }}$ picking & $4^{\text {th }}$ picking \\
\hline T1 & 1 & 1 & 3 & 3 \\
T2 & 2 & 3 & 4 & 5 \\
T3 & 2 & 2 & 3 & 4 \\
T4 & 2 & 2 & 5 & 4 \\
T5 & 2 & 3 & 4 & 5 \\
T6 & 3 & 4 & 5 & 5 \\
$P$ value & 0.109 & 0.078 & 0.075 & 0.197 \\
Chi - square & 9.00 & 9.90 & 10.00 & 7.33 \\
\hline
\end{tabular}

Table 10: Fruit length $(\mathrm{cm})$ with respect to treatment during the experiment period

\begin{tabular}{ccccc}
\hline Treatment & $1^{\text {st }}$ picking & $2^{\text {nd }}$ picking & $3^{\text {rd }}$ picking & $4^{\text {th }}$ picking \\
\hline T1 & $9.82 \pm 0.24 \mathrm{c}$ & $12.50 \pm 0.20$ & $10.10 \pm 0.24 \mathrm{~d}$ & $11.33 \pm 0.62 \mathrm{~b}$ \\
T2 & $15.33 \pm 1.00 \mathrm{a}$ & $15.33 \pm 0.23$ & $15.67 \pm 0.77 \mathrm{ba}$ & $16.00 \pm 0.20 \mathrm{a}$ \\
T3 & $13.33 \pm 0.42 \mathrm{ba}$ & $15.17 \pm 0.51$ & $13.60 \pm 0.34 \mathrm{bc}$ & $15.17 \pm 0.51 \mathrm{a}$ \\
T4 & $14.00 \pm 0.73 \mathrm{ba}$ & $14.50 \pm 1.27$ & $14.20 \pm 0.66 \mathrm{bac}$ & $15.50 \pm 0.20 \mathrm{a}$ \\
T5 & $12.17 \pm 0.23 \mathrm{bc}$ & $13.83 \pm 0.31$ & $13.17 \pm 0.23 \mathrm{c}$ & $12.83 \pm 0.51 \mathrm{~b}$ \\
T6 & $15.83 \pm 0.11 \mathrm{a}$ & $16.00 \pm 0.20$ & $16.00 \pm 0.20 \mathrm{a}$ & $16.17 \pm 0.42 \mathrm{a}$ \\
F test & $* *$ & $n s$ & $* *$ & $* *$ \\
\hline
\end{tabular}

Value represent mean $\mp$ standard error of four replicates. F test: - ns: not significant; $* *: P<0.01$; Means followed by the same letter in each column are not significantly different according to the Duncan's Multiple Range Test at 5\% level.

At $1^{\text {st }}, 2^{\text {nd }}$ and $4^{\text {th }}$ picking, maximum average girth of fruit was obtained in T6. At $4^{\text {th }}$ picking, girth of fruits did not significantly differ among treatments except $\mathrm{T} 1$. In line with present study, Colpan et al. (2013) reported that the lowest fruit diameter was obtained by the control dose and the highest fruit diameter was obtained by the potassium treated tomato plants. Further, they found that when potassium levels are low, fruits are small and when potassium is high, fruits are too large.

\section{Fresh and dry weights per fruit}

Fresh weight of okra fruit was significantly influenced $(\mathrm{P}<0.01)$ by the fruit peel powder application (Table 12). At $1^{\text {st }}, 2^{\text {nd }}$ and $3^{\text {rd }}$ pickings, and maximum fresh weight of fruit was observed in T6 while the lowest fresh weight of fruit was observed in T1. At $4^{\text {th }}$ picking, maximum fresh weight of fruit was observed in $\mathrm{T} 2$ while the lowest fresh weight of fruit was observed in T1. Colpan et al. (2013) stated that the lowest fruit fresh weight was obtained by the control dose and the highest fruit fresh weight was obtained by the potassium treated tomato plants. This is in line with present study.

At all the picking stages, maximum dry weight of fruit was observed in T6 and minimum fresh weight of fruit was observed in T1 (Table 13). At $3^{\text {rd }}$ and $4^{\text {th }}$ picking, maximum dry weight of fruit was observed in T6 (4.23 g and $4.59 \mathrm{~g}$ ) followed by T2 (3.13 g and $3.71 \mathrm{~g})$ while the lowest fresh weight of fruit was observed in T1 (1.62 g and $2.43 \mathrm{~g}$ ). Islam et al. (2004) noted that the highest value of the pod dry weight was observed in the bush-bean plant that received potassium under control condition, while the lowest value dry weight of pod was recorded in untreated plants.

\section{Number of seeds per fruit}

There was a significant difference $(\mathrm{P}<0.05)$ at $2^{\text {nd }}$, $3^{\text {rd }}$ and $4^{\text {th }}$ picking were confirmed with $P$ value of 0.027 and chi square value of 12.67 is shown 
in table 14. The highest number of seeds of 55, 54 and 59 were observed in T6 and the lowest number of seeds of 24, 20 and 20 were observed in $\mathrm{T} 1$ at $2^{\text {nd }}, 6^{\text {th }}$ and $4^{\text {th }}$ picking respectively. These results are in agreement with Bakry et al.(2016) who stated that the effect of foliar application of banana peel extract (500 and $1000 \mathrm{mg} / \mathrm{l}$ ) significantly increased seed weight per plant and 1000 seed weight of quinoa plants compared to the untreated plants.

Table 11: $\quad$ Fruit girth $(\mathrm{cm})$ with respect to treatment during the experiment period

\begin{tabular}{ccccc}
\hline Treatment & $1^{\text {st }}$ picking & $2^{\text {nd }}$ picking & $3^{\text {rd }}$ picking & $4^{\text {th }}$ picking \\
\hline T1 & $1.32 \pm 0.11 \mathrm{~b}$ & $5.00 \pm 0.01 \mathrm{~d}$ & $4.67 \pm 0.11$ & $4.67 \pm 0.23 \mathrm{~b}$ \\
T2 & $2.83 \pm 0.64 \mathrm{ba}$ & $6.67 \pm 0.11 \mathrm{ba}$ & $6.17 \pm 0.11$ & $6.33 \pm 0.11 \mathrm{a}$ \\
T3 & $2.05 \pm 0.24 \mathrm{~b}$ & $6.17 \pm 0.11 \mathrm{bc}$ & $5.83 \pm 0.31$ & $6.17 \pm 0.11 \mathrm{a}$ \\
T4 & $1.94 \pm 0.27 \mathrm{~b}$ & $6.33 \pm 0.11 \mathrm{bac}$ & $6.00 \pm 0.35$ & $6.17 \pm 0.11 \mathrm{a}$ \\
T5 & $2.64 \pm 0.09 \mathrm{ba}$ & $5.83 \pm 0.11 \mathrm{c}$ & $6.00 \pm 0.01$ & $6.00 \pm 0.01 \mathrm{a}$ \\
T6 & $4.07 \pm 0.49 \mathrm{a}$ & $7.00 \pm 0.35 \mathrm{a}$ & $6.33 \pm 0.47$ & $6.67 \pm 0.31 \mathrm{a}$ \\
F test & $* *$ & $* *$ & $\mathrm{~ns}$ & $* *$ \\
\hline
\end{tabular}

Value represent mean $\mp$ standard error of four replicates. F test: - ns: not significant; $* *: P<0.01$; Means followed by the same letter in each column are not significantly different according to the Duncan's Multiple Range Test at 5\% level.

Table 12: $\quad$ Fresh weight $(\mathrm{g})$ of fruit with respect to treatment during the experiment period

\begin{tabular}{ccccc}
\hline Treatment & $1^{\text {st }}$ picking & $2^{\text {nd }}$ picking & $3^{\text {rd }}$ picking & $4^{\text {th }}$ picking \\
\hline T1 & $12.82 \pm 0.50 \mathrm{c}$ & $15.60 \pm 0.19 \mathrm{~d}$ & $14.72 \pm 0.42 \mathrm{~b}$ & $14.83 \pm 0.26 \mathrm{c}$ \\
T2 & $19.11 \pm 0.36 \mathrm{~b}$ & $20.52 \pm 0.58 \mathrm{~b}$ & $20.01 \pm 0.36 \mathrm{a}$ & $21.02 \pm 0.58 \mathrm{a}$ \\
T3 & $17.24 \pm 0.03 \mathrm{~b}$ & $19.54 \pm 0.34 \mathrm{bac}$ & $18.14 \pm 0.03 \mathrm{a}$ & $20.04 \pm 0.34 \mathrm{ba}$ \\
T4 & $17.17 \pm 0.42 \mathrm{~b}$ & $18.73 \pm 1.06 \mathrm{bc}$ & $18.07 \pm 0.42 \mathrm{a}$ & $19.23 \pm 1.06 \mathrm{ba}$ \\
T5 & $17.76 \pm 1.11 \mathrm{~b}$ & $17.87 \pm 0.32 \mathrm{dc}$ & $18.66 \pm 1.11 \mathrm{a}$ & $18.37 \pm 0.32 \mathrm{~b}$ \\
T6 & $22.26 \pm 1.11 \mathrm{a}$ & $21.46 \pm 0.38 \mathrm{a}$ & $20.50 \pm 0.33 \mathrm{a}$ & $20.63 \pm 0.32 \mathrm{ba}$ \\
F test & $* *$ & $* *$ & $* *$ & $* *$ \\
\hline
\end{tabular}

Value represent mean $\mp$ standard error of four replicates. $F$ test: - **: $P<0.01$; Means followed by the same letter in each column are not significantly different according to the Duncan's Multiple Range Test at 5\% level.

Table 13: Dry weight (g) of fruit with respect to treatment during the experiment period

\begin{tabular}{ccccc}
\hline Treatment & $1^{\text {st }}$ picking & $2^{\text {nd }}$ picking & $3^{\text {rd }}$ picking & $4^{\text {th }}$ picking \\
\hline T1 & $1.31 \pm 0.11 \mathrm{~b}$ & $1.93 \pm 0.03 \mathrm{~d}$ & $1.62 \pm 0.11 \mathrm{~b}$ & $2.43 \pm 0.03 \mathrm{~d}$ \\
T2 & $2.83 \pm 0.64 \mathrm{ba}$ & $3.21 \pm 0.19 \mathrm{~b}$ & $3.13 \pm 0.64 \mathrm{ba}$ & $3.71 \pm 0.19 \mathrm{~b}$ \\
T3 & $2.05 \pm 0.24 \mathrm{~b}$ & $2.27 \pm 0.05 \mathrm{~cd}$ & $2.35 \pm 0.24 \mathrm{~b}$ & $2.77 \pm 0.05 \mathrm{~cd}$ \\
T4 & $1.94 \pm 0.27 \mathrm{~b}$ & $2.46 \pm 0.31 \mathrm{~cd}$ & $2.26 \pm 0.27 \mathrm{~b}$ & $2.63 \pm 0.31 \mathrm{~d}$ \\
T5 & $2.64 \pm 0.09 \mathrm{ba}$ & $2.92 \pm 0.09 \mathrm{cb}$ & $2.94 \pm 0.09 \mathrm{ba}$ & $3.42 \pm 0.09 \mathrm{cb}$ \\
T6 & $4.07 \pm 0.49 \mathrm{a}$ & $4.08 \pm 0.07 \mathrm{a}$ & $4.23 \pm 0.45 \mathrm{a}$ & $4.59 \pm 0.07 \mathrm{a}$ \\
F test & $*$ & $* *$ & $*$ & $* *$ \\
\hline
\end{tabular}

Value represent mean $\mp$ standard error of four replicates. $F$ test: - *: $P<0.05$; *: $P<0.01$; Means followed by the same letter in each column are not significantly different according to the Duncan's Multiple Range Test at 5\% level. 
Table 14: Number of seeds per fruit with respect to treatment during the experiment period

\begin{tabular}{ccccc}
\hline Treatment & $1^{\text {st }}$ picking & $2^{\text {nd }}$ picking & $3^{\text {rd }}$ picking & $4^{\text {th }}$ picking \\
\hline T1 & 13 & 24 & 20 & 20 \\
T2 & 44 & 50 & 51 & 54 \\
T3 & 39 & 40 & 38 & 44 \\
T4 & 40 & 30 & 31 & 46 \\
T5 & 40 & 28 & 28 & 36 \\
T6 & 53 & 55 & 54 & 59 \\
$P$ value & 0.206 & 0.027 & 0.027 & 0.027 \\
Chi - square & 7.20 & 12.67 & 12.67 & 12.67 \\
\hline
\end{tabular}

Table 15: Total yield (tons/ha) at each picking with respect to treatment during the experiment period

\begin{tabular}{ccccc}
\hline Treatment & $1^{\text {st }}$ picking & $2^{\text {nd }}$ picking & $3^{\text {rd }}$ picking & $4^{\text {th }}$ picking \\
\hline T1 & $0.23 \pm 0.01 \mathrm{c}$ & $0.37 \pm 0.06 \mathrm{c}$ & $0.61 \pm 0.11$ & $0.81 \pm 0.12$ \\
T2 & $0.69 \pm 0.01 \mathrm{ba}$ & $0.97 \pm 0.07 \mathrm{~b}$ & $1.31 \pm 0.22$ & $1.77 \pm 0.13$ \\
T3 & $0.52 \pm 0.07 \mathrm{bc}$ & $0.82 \pm 0.08 \mathrm{~b}$ & $0.87 \pm 0.08$ & $1.44 \pm 0.14$ \\
T4 & $0.52 \pm 0.07 \mathrm{bc}$ & $0.78 \pm 0.07 \mathrm{~b}$ & $1.44 \pm 0.30$ & $1.30 \pm 0.28$ \\
T5 & $0.64 \pm 0.04 \mathrm{ba}$ & $0.96 \pm 0.02 \mathrm{~b}$ & $1.36 \pm 0.18$ & $1.44 \pm 0.17$ \\
T6 & $0.90 \pm 0.16 \mathrm{a}$ & $1.41 \pm 0.08 \mathrm{a}$ & $1.84 \pm 0.03$ & $1.99 \pm 0.12$ \\
F test & $*$ & $* *$ & $\mathrm{~ns}$ & $\mathrm{Ns}$ \\
\hline
\end{tabular}

Value represent mean $\mp$ standard error of four replicates. F test: - *: $P<0.05 ; * *: P<0.01 ;$ Means followed by the same letter in each column are not significantly different according to the Duncan's Multiple Range Test at 5\% level.

\section{Total yield at each picking (tons/ha)}

Application of different fruit peel powder significantly influenced $(\mathrm{P}<0.05)$ total yield in $1^{\text {st }}$ and $2^{\text {nd }}$ picking (Table 15). There was no significant difference $(\mathrm{P}>0.05)$ at $3^{\text {rd }}$ and $4^{\text {th }}$ picking. At $1^{\text {st }}$ and $2^{\text {nd }}$ picking, the highest value was obtained in T6 and the lowest value in T1. It is agreeable with Bakry et al. (2016) who stated that effect of foliar application of banana peel extract significantly increased the yield of quinoa plants.

\section{CONCLUSIONS}

The results reveal that application of fruit peel powder at basal and top dressing had significant differences $(\mathrm{P}<0.05)$ on plant height, number of leaves per plant, leaf area, chlorophyll content, days to $50 \%$ and $100 \%$ flowering, dry weights of leaves, stem, root and fruit, fruit length and girth. Further at $1^{\text {st }}, 2^{\text {nd }}, 3^{\text {rd }}$ and $4^{\text {th }}$ picking, the highest value was obtained in T6 and the lowest value in T1. Present study can be suggested that among the all tested treatments, half recommended fertilizer application at basal and topdressing times with $0.5 \mathrm{~g}$ each of orange and banana peel powders at both times (T6) would be the most suitable to get optimum growth and yield of okra in sandy regosol. 


\section{REFERENCES}

Ajayi, E.O., Adeoye, I.B. and Shittu, O.A. (2017). Economic analysis of intercropping okra with legumes. Journal of Agricultural Sciences. 62(2): 193-202. https://doi.org/10.2298/jas1702193a

Akanbi, W.B., Togun, A.O., Rewatkar, S.S., Anjali, M. and Shelke, T.S. (2010). Growth and dry matter and fruit yields components in okra under organic and inorganic sources of nutrients. American Eurasian Journal Sustainable Agriculture. 4(1): 1-13. https://doi.org/10.4314/njhs. v14i1.62155

Amin, M.R., Karim, M.A., Khaliq, Q.A., Islam, M.R. and Aktar, S. (2015). Effect of nitrogen and potassium on the root growth, nutrient content and yield of mungbeans under waterlogged condition. A Scientific Journal of krishi Foundation. 13(1): 67-78. https://doi.org/10.3329/ agric.v13i1.26549

Anhwange, B.A., Ugye, B.A. and Nyiaatagher, T.D. (2009). Chemical composition of Musa sapientum (banana) peels. Electronic Journal of Environmental. 8(6): 437-442.

Bakry, A.B., Ibrahim, F.M., Abdallah, M.M.S. and Bassiouny, H.M.S. (2016). Effect of banana peel extract or tryptophan on growth, yield and some biochemical aspects of quinoa plants under water deficit. International Journal of Pharm Tech Research.9(8): 276-287.

Colpan, E., Zengin, M. and Ozbahce, A. (2013). The effects of potassium on the yield and fruit quality components of stick tomato. Horticulture Environment Biotechnology. 54(1): 20-28. https:// doi.org/10.1007/s13580-013-0080-4

Ding, Y., Wang, Z., Ren, M., Zhang, P., Li, Z., Chen, S., Ge, C., and Wang, Y. (2018). Iron and callose homeostatic regulation in rice roots under low phosphorous. Plant Biology. 18: 1-5. https://doi. org/10.1186/s12870-018-1486-Z

Dubey, P. and Mishra, S. (2017). Effect of okra seed in reduction of cholesterol. Journal of Entomology and Zoology Studies. 5(4): 94-97.

Fageria, N.K. and Moreira, A. (2011). The role of mineral nutrition on root growth of crop plants. Advances in Agronomy. 110: 251-255. https://doi.org/10.1016/b978-0-12-385531-2.00004-9

Fatemeh, S.R., Saifullah, R., Abbas, F.M.A. and Azhar, M.E. (2012). Total phenolics, flavonoids and antioxidant activity of banana pulp and peel flours: influence of variety and stage of ripeness. International Food Research Journal. 19(3): 1041-1046.

Gemede, H.F., Ratta, N., Haki, G.D., Beyene, F. and Woldegiorgis, A.Z. (2015). Nutritional quality and health benefits of okra (Abelmoschusesculentus): a review. American Journal of Food Science and Nutrition. 2(1): 1-8.

Ibeawuchi, I.I., Obiefuna, J.C. and Ofoh, M.C. (2005). Effects of row spacing on yield and yield components of okra (Abelmoschusesculentus) and mixture groundnut (Archishypogaea). Journal of Agronomy. 4(4): 304-307. https://doi.org/10.3923/ja.2005.304.307

Ibrahim, U.K., Kamarrudin, N., Suzihaque, M.U.H. and Hashib, S.A. (2016). Local fruit wastes as a potential source of natural antioxidant: an overview. IOP Conference Series: Materials Science and Engineering. 206: 1-3. https://doi.org/10.1088/1757-899x/206/1/012040

Islam, M.S., Haque, M.M., Khan, M.M., Hidaka, T. and Karimi, M.A. (2004). Effect of fertilizer potassium on growth, yield and water relations of bushbean (Phaseolus vulgaris L.) under water stress conditions. Japanese Journal of Tropical Agriculture. 48(1): 1-9. 
Ismail, T., Sestili, P. and Akhtar, S. (2012). Pomegranate peel and fruit extracts: a review of potential anti-inflammatory and anti-infective effects. Journal of Ethnopharmacology. 143: 397-405. https://doi.org/10.1016/j.jep.2012.07.004

Jariwala, H.J. and Syed, H.S. (2016). Study on use of fruit peels powder as a fertilizer. National Conference on Recent Advances in Environmental Science and Engineering Technologies. 1-3.

Javid, Q.A., Abbasi, N.A., Hafiz, I.A. and Mughal, A.L. (2005). Performance of Zinnia (Zinnia elegans) dahlia flowered crimson shade by application of NPK fertilizer. International Journal of Agriculture and Biotechnology. 7(3): 474-476.

Joiner, J.N. and Gruis, J.T. (1961). Effect of nitrogen and potassium levels on growth, flowering and chemical composition of zinnia and marigold. Florida State Horticulture Science. 8: 445-448.

Kadir, A.A., Rahman, N.A. and Azhari, N.W. (2016). The utilization of banana peel in the fermentation liquid in food waste composting. IOP Conference Series: Materials Science and Engineering. 136: 1-8. https://doi.org/10.1088/1757-899x/136/1/012055

Kang, J. and Iersel, M.W. (2004). Nutrients solution concentration affects shoot: root ratio, leaf area ratio, and growth of sub irrigated salvia. Horticulture Science. 39(1): 49-54. https://doi. org/10.21273/hortsci.39.1.49

Larik, K.K., Shafkh, M.A., Kakar, A.A. and Shaikh, M.A. (1999). Effect of nitrogen and potassium fertilization on morphological traits on Zinnia elegans. Pakistan Journal of Agricultural Science. 36 (1-2): 20-22.

Mazed, H.E.M.K., Moonmoon, J.F., Haque, N., Pulok, A.I. and Rahman, H. (2015). growth and yield of mungbean as influenced by potassium and sulphur. Annals of Biological Research. 6(1): 6-10.

Mercy, S., Mubsira, B.S. and Jenifer, I. (2014). Application of different fruit peels formulations as a natural fertilizer for plant growth. International Journal of Scientific \& Technology Research. 3(1): 300-307.

Rafiq, S., Kaul, R., Sofi, S.A., Bashir, N., Nazir, F. and Nayik, G.A. (2018). Citrus peel as a source of functional ingredient: a review. Journal of the Saudi Society of Agriculture Sciences. 17: 351358. https://doi.org/10.1016/j.jssas.2016.07.006

Rowayshed, G., Salama, A., Abul-Fadl, M., Akila-Hamza, S. and Emad, A.M. (2013). Nutritional and chemical evaluation for pomegranate (Punicagranatum L.) fruit peel and seeds powders by products. Middle East Journal of Applied Sciences. 3(4): 169-179.

Sachan, S., Sing, D., Kasera, S., Mishra, S.K., Tripathi, Y., Mishra, V. and Singh, R.K. (2017). Intergrated nutrient management (INM) in okra (Abelmoschusesculentus (L.) Monech) for better growth and high yield. Journal of Pharmacognosy and Phytochemistry. 6(5): 1854-1856.

Sakpere, A.M.A., Bankole, M., Oyekola, O.B., Akinyemi, O.S., Akosile, O.R., Adegboye, O.A., Akinropo, M.S. and Obisesan, I.A. (2018). Effect of different Moringaoleifera extracts and fruit peels on the growth of Solanumscabrum. International journal of Biological Science. 12(4): 1543-1549. https://doi.org/10.4314/ijbcs.v12i4.2

Shah, S.N.M., Ali, A., Amin, N., Shah, M. and Khan, A. (2014). Potassium influence on flowering and morphology of Zinnia elegans. International Journal of Farming and Allied Sciences. 3(4): 377-381. 
Shahid, M.R., Amjad, M., Ziaf, K., Jahangir, M.M., Ahmad, S., Iqbal, Q. and Nawaz, A. (2013). Growth, yield and seed production of okra as influenced by different growth regulators. Pakistan Journal of Agriculture Science. 50(3): 387-392.

Singh, M.D., Chirag, G., Prakash, P.O., Mohan, M.H., Prakash, G. And Vishwajith. (2017). Nano fertilizers is a new way to increase nutrients use efficiency in crop production. International Journal of Agriculture Sciences. 9(7): 3831-3833.

Singh, S. and Prasad, S.M. (2014). Growth, photosynthesis and oxidative responses of Solanummelongena L. seedlings to cadmium stress: Mechanism of toxicity amelioration by kinetin. ScientiaHorticulturae. 176: 1-10. https://doi.org/10.1016/j.scienta.2014.06.022

Tan, N. and So, R.C. (2018). Biochar from waste banana peels as growth promoter for holy basil (Ocimumtenuiflorum) and chili pepper (Capsicum annum). Available online: https://briefs. techconnect.org (accessed on 4.12.2019).

Wazir, A., Gul, Z. and Hussain, M. (2018). Comparative study of various organic fertilizers effect on growth and yield of two economically important crops, potato and pea. Agricultural Science. 9: 703-717. https://doi.org/10.4236/as.2018.96049 